\title{
Obituaries
}

Obituaries should be submitted by email to Kate Maynard at k.maynard@nature.com.

All submitted obituaries should be 350 words maximum in length (apart from obituaries for past presidents of the BDA where the length should be $700-800$ words).

Content of the obituary is down to the individual author, and the approval of the family should be given for the obituary prior to submission to the $B D J$.

\section{MAURICE JOHN GILMOUR}

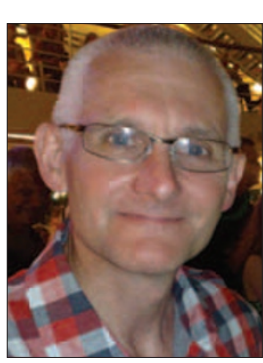

St Nicholas

Church, Codsall, was packed on 8 August this year as family, friends and colleagues joined in a Service of Thanksgiving to celebrate the

life of John Gilmour. All those present had been shocked and saddened by his unexpected death at the age of 54 .

Born in Oldham, John graduated from Birmingham University School of Dentistry in 1980, after which he was offered, and accepted, the Wolverhampton House Job. It was here that the seeds of his later professional success were sown, his quiet self-effacing manner, diligence, sense of humour and attention to detail endearing himself to patients and colleagues alike. John later worked in general practice in Chasetown where he soon became a loyal and caring team player. It was here that a lifelong interest in vocational training (VT) was fostered. He was appointed as a trainer on seven occasions, and was a major force in modifying the original VT portfolio book.

He was appointed Vocational Training Advisor for the Stafford scheme in 2003 and in 2009 was delighted to accept the post of Associate Postgraduate Dental Dean for NHS West Midlands, responsible for all first year VT. In his short time in that role he set up two new training schemes and implemented a streamlined and innovative system of region-wide recruitment.

Away from his professional duties John pursued a hectic and eclectic lifestyle. His family were central to this and he devoted himself tirelessly to nurturing the diverse and considerable talents of his three children, Claudia, Nick and Amelia.

A lifelong football fan, John was a member of the England Supporters Club; in his younger days he played and was known as a combative midfielder in the Wolverhampton amateur leagues. A knee injury curtailed his footballing career but could not prevent him completing the London marathon. He ran half-marathons for fun and completed the Great North Run on three occasions.

John was a role model in all the various facets of his life and will be sadly missed by all who knew him. He is survived by his wife Serena and their three children.

\section{WILLIAM SYDNEY GRACE}

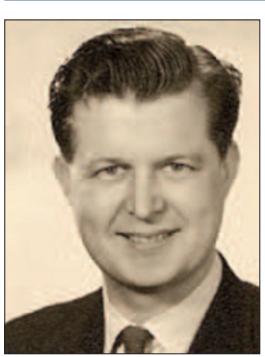

William Sydney Grace (known as Bill) was born in Seaforth on 22 June 1919. Following his education at Merchant Taylor's he met his childhood sweetheart Moira Peverley at 15, and they were married in 1940. Bill volunteered for the RAF the day war was declared, but wasn't posted overseas until 1943 where he was involved in intelligence. He rarely spoke about his experiences during the war, apart from vivid memories of being dive-bombed by Japanese kamikaze pilots. He was on his way to be placed behind the Japanese lines when luckily the war ended.

After being demobbed in May 1946 Bill decided to study dentistry at the
London Hospital in Whitechapel, and he qualified in 1951. At first he worked in a number of practices around London, but in 1953 he set up his own NHS practice in Banstead, Surrey, and quickly built a thriving practice. He was a trendsetter in providing music for his patients to listen to during their treatment, and would often seem to spend more time selecting the most appropriate music on his tape recorder than actually carrying out the dentistry.

He enjoyed his dentistry, and would have liked to continue his studies to become a maxillofacial surgeon, but the need to provide for his family prevented this. He built up a successful practice, but the long hours and pressure of patient demand affected his health and he was advised by his doctor that he had to convert to private care if he wished to continue. He moved to Harley Street where many of his patients followed him, and continued his successful career until eventually he retired in 1987. This allowed him to spend more time with his family as he and Moira moved to a mobile home near Tring. The life was ideal for them, as being keen caravanners for many years meant they now lived perpetually 'on holiday'.

Eventually ill health meant a move back to Ewell in Surrey to be near his daughter, and he died on 18 August 2011 after a short battle with prostate cancer. He is survived by his widow and three children.

Michael Grace 